UCRL-ID-129183

\title{
Transport of Soluble Species Through Tuff Core
}

Brian E. Viani

Leslie Carman

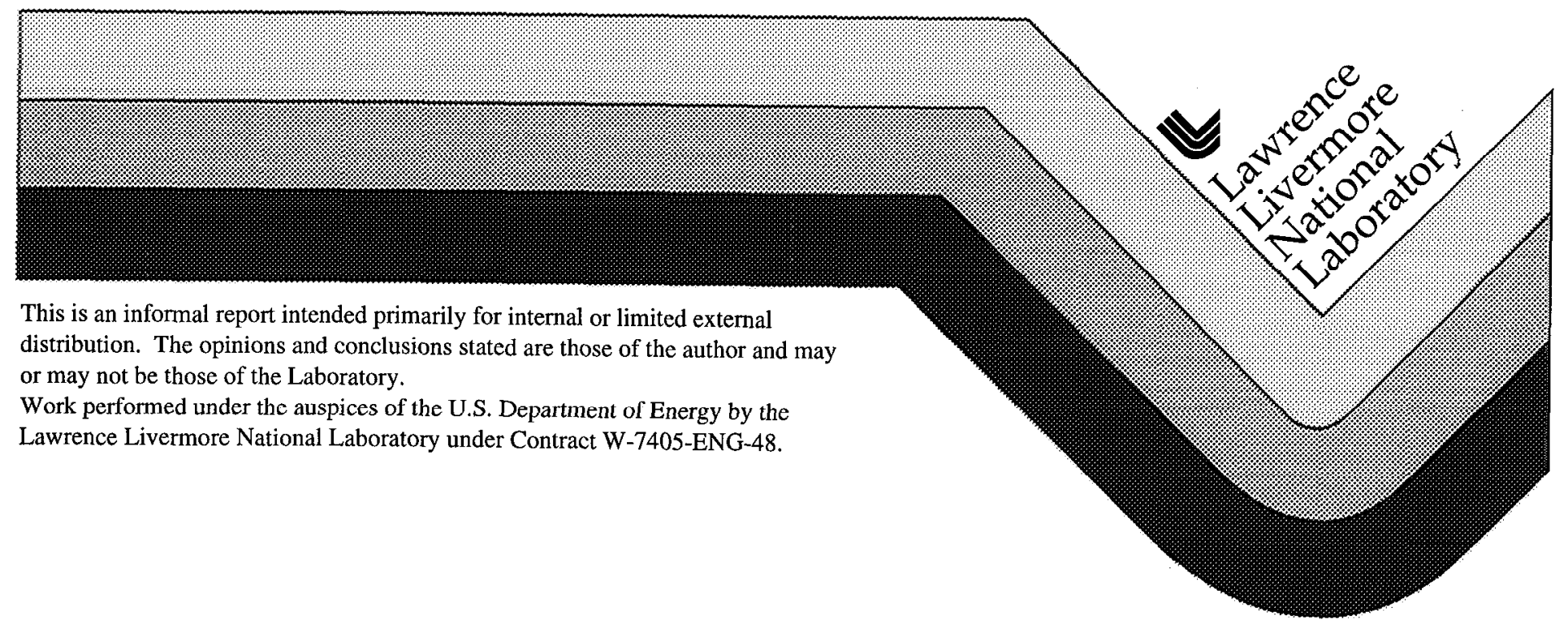




\section{DISCLAIMER}

This document was prepared as an account of work sponsored by an agency of the United States Government. Neither the United States Government nor the University of California nor any of their employees, makes any warranty, express or implied, or assumes any legal liability or responsibility for the accuracy, completeness, or usefulness of any information, apparatus, product, or process disclosed, or represents that its use would not infringe privately owned rights. Reference herein to any specific commercial product, process, or service by trade name, trademark, manufacturer, or otherwise, does not necessarily constitute or imply its endorsement, recommendation, or favoring by the United States Government or the University of California. The views and opinions of authors expressed herein do not necessarily state or reflect those of the United States Government or the University of California, and shall not be used for advertising or product endorsement purposes.

This report has been reproduced directly from the best available copy.

Available to DOE and DOE contractors from the Office of Scientific and Technical Information

P.O. Box 62, Oak Ridge, TN 37831

Prices available from (423) 576-8401

Available to the public from the National Technical Information Service

U.S. Department of Commerce 5285 Port Royal Rd.

Springfield, VA 22161 


\section{Transport of Soluble Species Through Tuff Core - MOL52 \\ Brian Viani \\ Leslie Carman \\ LLNL}

This letter report presents and summarizes results of flow and tracer tests using a core sample of Topopah Spring tuff containing a saw-cut fracture. A dilute $\mathrm{Na}-\mathrm{Cl}-\mathrm{HCO}_{3}$ solution containing $\mathrm{Br}{ }^{-}$or $\mathrm{I}^{-}$ tracer was eluted through the core under constant flow conditions $(0.1,0.2,2.0 \mathrm{~mL} / \mathrm{h})$ and at three temperatures $\left(23,59,92^{\circ} \mathrm{C}\right)$. A more complete analysis of these data and the implications of these results for transport of soluble species in the Topopah Spring tuff in the Near Field Environment (NFE) will be reported in the synthesis of Integrated Testing activities to be included in the NFE Report.

\section{Summary of experimental procedures}

Experiments were undertaken using a $5.08 \mathrm{~cm}$ diameter $5.41 \mathrm{~cm}$ long cylindrical core of Topopah Spring tuff (USW GU3; $1153 \mathrm{ft}$ depth; ID 0017348.2). A saw-cut parallel to the length of the core was made and two $1 / 8$ inch wide $1 \mathrm{mil}(\sim 25 \mu \mathrm{m})$ thick gold shims inserted to maintain a fixed aperture between the surfaces. The core sample was mounted in an apparatus in which confining pressure, downstream pore pressure, flow rate, and core temperature could be varied (Figure 1). Pressures, temperatures and flow rate were monitored and periodically logged to a computer. Details of the apparatus and the sample treatment are given in Viani and Martin $(1993,1994)$. Table 1 summarizes the flow tests that have been considered for this report.

Volume accuracy - The volume of fluid passing through the core and collected by the fraction collector was compared with the dispensed volume indicated by the pump and with the volume calculated using the nominal flow rate and the elapsed time (Table 2). Accurate fraction volumes were obtained by weighing the collection tubes before and after fractions were collected. As might be expected, the agreement between these three volumes was better for the fast flow rate, i.e. shorter $(14 \mathrm{~h})$ experiments. At $2.0 \mathrm{~mL} / \mathrm{h}$ the measured fractions contained $99 \%$ of the indicated delivered volume. At $0.2 \mathrm{~mL} / \mathrm{h}$ the measured fractions contained $92 \%$ of the delivered volume. The lower recovery probably represents a small amount of evaporation over the course of the 6 day experiment even though the fractions were

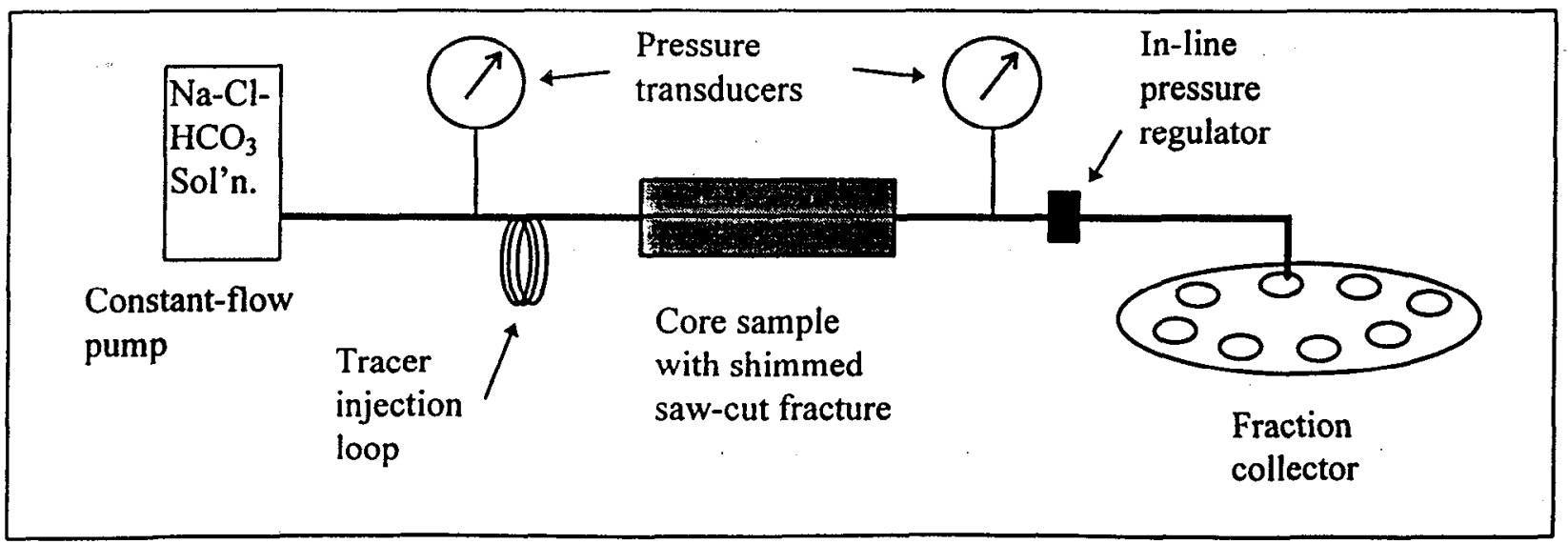

Figure 1. Schematic diagram of flow-test system. 
capped and stored at $4^{\circ} \mathrm{C}$ each day and the fraction collector was covered during the experiment.

Pressure control - All experiments were run using the constant flow feature of the delivery pump. Under constant flow conditions sample permeability and tracer pulse breakthrough were sensitive to the confining pressure and the pore pressure, respectively. The pore pressure is the average of the up and downstream pore pressures. In order to control downstream pore pressure more closely, the needle valve used to control downstream pressure was replaced (6/29/95) with a back pressure regulator which " allowed for nominally constant downstream pressure. Because confining pressure was not constant, but varied between 35 and 50 bar, variation in permeability during the course of a run was unavoidable (Figure 2).

Tracer Experiments - Following a period of flow of the standard feed solution $(60 \mathrm{ppm} \mathrm{Na}, 86 \mathrm{ppm} \mathrm{Cl}$, $10.6 \mathrm{ppm} \mathrm{HCO} 3, \mathrm{pH} \sim 7.5)$, a $560 \mu \mathrm{L}$ pulse of either $\mathrm{NaBr}$ or $\mathrm{NaI}$ tracer solution $(0.75 \mathrm{mM})$ was injected upstream from the core. The average recovery of the $\mathrm{NaBr}$ tracer downstream from the core was $95 \%$. On 7/19/95 the tracer was changed to NaI because of increased analytical sensitivity (Figure 3). Because it was possible to analyze smaller samples we were able to collect smaller fractions. Under these conditions the recovery of $\mathrm{NaI}$ tracer was $102 \%$. Both $\mathrm{Br}^{-}$and $\mathrm{I}^{-}$are considered to be conservative (nonretarded) tracers under the conditions of these experiments.

In order to determine the effect of the upstream tubing on the shape of the tracer pulse, a Harvard syringe pump was used to pump $500 \mu \mathrm{L}$ samples of the standard $0.75 \mathrm{mM} \mathrm{Nal}$ tracer through $70 \mathrm{~cm}$ of $1 / 16^{\text {" ID }}$ tubing at 0.2 and $2.0 \mathrm{~mL} / \mathrm{h}$ flow rates at ambient temperature. The shape of the tracer peak was determined by analyzing $\sim 0.1 \mathrm{~mL}$ fractions (Figure 4 ). At the higher flow rate the pulse is slightly distorted and broadened compared to the slower flow rate. However, at each flow rate the full width at half maximum concentration (FWHM) is very near $0.5 \mathrm{~mL}$; that is, the pulse of tracer is eluted from the tubing without significant dispersion. In comparison, the FWHM's of the $560 \mu \mathrm{L}$ tracer pulses passing through the core sample were 2 to 15 times larger.

Chemical analysis of fluid samples - Inductively coupled plasma spectroscopy (ICP) was used to analyze samples of the influent feed solution, and of the effluent from the core before, during, and following the elution of the tracer pulse for flow tests FT041495MLC $\left(23^{\circ} \mathrm{C} ; 0.2 \mathrm{~mL} / \mathrm{h}\right)$, FT080695MLC $\left(92^{\circ} \mathrm{C}, 0.2\right.$ $\mathrm{mL} / \mathrm{h})$, and $\mathrm{FT} 081495 \mathrm{MLC}\left(92^{\circ} \mathrm{C} ; 2.0 \mathrm{~mL} / \mathrm{h}\right)$. The solution $\mathrm{pH}$ was measured electrometrically on selected samples.

\section{Results and discussion}

Summary of flow results - The average permeability at $23^{\circ} \mathrm{C}$ was on the order of 0.06 millidarcy and was independent of the flow rate and average pore pressure (Table 1). This value is approximately one third to one fifth that of the lowest permeabilities previously observed for the same sample (Viani and Martin, 1994) and for a different sample having the same fracture aperture (Viani and Martin, 1993). This may reflect the growth of a bacterial population in the fracture channel as noted by Viani and Martin (1993), or may reflect small differences in fracture aperture (see below). The presence of bacteria in the fracture will be assessed when the sample is removed from the flow-test device. The observed permeability is almost 2 orders of magnitude smaller than would be predicted (de Marsily, 1986) for a $25 \mu \mathrm{m}$ aperture with smooth walls. At $59^{\circ} \mathrm{C}$, the average permeability is slightly larger $(\sim 0.1$ millidarcy) and also appeared to be independent of the flow rate and average pore pressure.

At $92{ }^{\circ} \mathrm{C}$ the average permeability varied between 0.08 and 2.34 millidarcy and was independent of the flow rate but dependent on average pore pressure. For runs in which the average pore pressure was less than 0.1 bar ( 5 runs) the average permeability was $\sim 0.2$ millidarcy. For runs in which the average pore pressure was greater than 0.5 bar ( 7 runs) the average permeability was 1.9 millidarcy. If one assumes all the flow is via the fracture, the effective aperture width is calculated to be 9.6 and $4.5 \mu \mathrm{m}$, respectively. These widths are significantly smaller than the $25 \mu \mathrm{m}$ assumed to be maintained by the gold shim. It is possible that some reduction in the shim thickness may have occurred upon loading. This will be assessed after the sample is removed from the apparatus. Deformation of the core sample itself under confining pressure may also contribute to the low permeabilities observed. 
Table 1. Summary of flow-through experiments

\begin{tabular}{|c|c|c|c|c|c|c|c|c|}
\hline Experiment ${ }^{l}$ & $\begin{array}{l}\text { Core } \\
\text { Temp. } \\
\left({ }^{\circ} \mathrm{C}\right)\end{array}$ & $\begin{array}{l}\text { Flow } \\
\text { rate }^{2} \\
(\mathrm{~mL} / \mathrm{h})\end{array}$ & \multicolumn{2}{|c|}{$\begin{array}{c}\text { Downstream } \\
\text { pressure }^{3}\end{array}$} & $\begin{array}{l}\text { Average } \\
\text { pore } \\
\text { pressure } \\
\text { (bar) }\end{array}$ & $\begin{array}{l}\text { Average } \\
\text { differential? } \\
\text { pressure } \\
\text { (bar) }\end{array}$ & $\begin{array}{c}\text { Average } \\
\text { permeability } \\
\text { (millidarcy) }\end{array}$ & Tracer? \\
\hline FT040395MLC & 23 & 2.0 & none & 0.002 & 1.30 & 2.64 & 0.053 & $\mathrm{NaB}$. \\
\hline FT040495MLC & 23 & 0.1 & none & 0.001 & 0.095 & 0.18 & 0.059 & NaB? \\
\hline FT041395MLC & 23 & 2.0 & 0.9 (start) & 0.95 & 2.01 & 212 & 0.065 & $\mathrm{NaB}$. \\
\hline FT041495MLC & 23 & 0.2 & 0.3 (start) & 0.36 & 0.47 & 025 & 0.059 & Nabr: \\
\hline FT042795MLC & 59 & 2.0 & 1.0 (start) & 1.26 & 1.62 & 072 & 0.094 & NaBr \\
\hline FT050295MLC & 59 & 0.2 & 0.9 (start) & 2.51 & 2.5 & 0.082 & 0.092 & Nabs: \\
\hline FT051095MLC & 59 & 2.0 & none & 0.047 & 0.27 & 045 . & 0.15 & WaBt \\
\hline FT051295MLC & 59 & 0.2 & none & 0.035 & 0.084 & 011 & 0.067 & $\mathrm{NaB}$ \\
\hline FT060295MLC & 92 & 0.2 & none & 0.048 & 0.071 & 0.048 & 0.11 & NaBt: \\
\hline FT061295MLC & 92 & 2.0 & none: & 0.53 & 0.54 & 0.036 & 1.84 & $\sqrt{ } \times a_{3}$. \\
\hline FT061395MLC & 92 & 2.0 & 0.9 (start) & 3.05 & 3.06 & 0.028 & 2.33 & Nass. \\
\hline FT061595MLC & 92 & 0.2 & 09 (start) & 2.88 & 2.88 & 0.0099 & 1.29 & Nabr: \\
\hline FT062995MLC & 92 & 0.2 & 10 (constant) & 102 & 1.02 & 0.0084 & 2.24 & NaBn: \\
\hline FT071995MLC & 92 & 2.0 & 1.0 (constant) & 1.09 & 1.10 & 0.029 . & 1.92 & Nâ. \\
\hline FT072495MLC & 92 & 2.0 & 10 (constant) & 117 & 1.19 & 0.044 . & 1.16 & nat. \\
\hline FT072695MLC & 92 & 2.0 & none & 0.019 & 0.091 & 0.16. & 0.29 & Nà \\
\hline FT080695MLC & 92 & 0.2 & none & 0.032 & 0.057 & 0.059 & 0.083 & Nar. \\
\hline FT081495MLC & 92 & 2.0 & none & 0.019 & 0.070 & 0.12 & 0.38 & Nart: \\
\hline FT081695MLC & 92 & 0.2 & none & 0.036 & 0.062 & 0.061 . & 0.081 & Nar \\
\hline FT082395MLC & 92 & 0.2 & 10 (constant) & 1.12 & 1.12 & 0.0063 & 2.21 & Nar \\
\hline
\end{tabular}

${ }^{1}$ Identifier for each experiment includes date the test was begun in the format month-day-year.

${ }^{2}$ Nominal flow rate as set by piston pump.

${ }^{3}$ Pressure measured by transducer connected between the outflow from core-sample and a downstream metering valve and/or backpressure regulator. For runs prior to 6/29/95 the downstream pressure was set at the beginning of each experiment by adjusting the downstream metering valve. An in-line flow-through constant pressure regulator (Rainin) was used to maintain the downstream pressure for experiments beginning 6/29/95.

${ }^{4}$ Differential pressure was measured using a differential pressure transducer or calculated from the difference between the up and down stream pore-pressure transducer readings. In general, these readings agreed closely (Viani and Martin, 1993). Average values were computed by taking the mean of every 10 th value of the instantaneous transducer readings for the 0.1 and $0.2 \mathrm{~mL} / \mathrm{h}$ runs, and every reading for the $2.0 \mathrm{~mL} / \mathrm{hr}$ runs.

${ }^{3}$ The permeability was calculated based on the nominal flow rate, the cross-sectional area and length of the coresample, the viscosity of the fluid at the core temperature, and the average differential pressure across the core.

${ }^{6}$ The tracer used in these tests was changed from $\mathrm{Br}^{-}$to $\mathrm{I}^{-}$to because of the greater analytical sensitivity using the ion-selective electrode which allowed greater precision in identifying the tailing region of the tracer breakthrough curves. 
It is clear that pore pressure has a significant effect on the permeability at $92{ }^{\circ} \mathrm{C}$. This effect is nonlinear; i.e., increasing pore-pressure above a threshold does not result in a continued increase in permeability. The fact that permeability is dependent on pore pressure only for the high-temperature runs is not readily explainable. However, the phenomenon does appear to be reasonably reversible (Table 1). If the phenomenon were related to changes in aperture width, a reversible change of $\sim 5 \mu \mathrm{m}$ would be required.

Table 2. Comparison of measured collected volume with indicated pump volume and with volume calculated from nominal flow rate and elapsed time.

\begin{tabular}{lccccc}
\hline Experiment & Flow rate & $\begin{array}{c}\text { Indicated pump } \\
\text { volume } \\
(\mathrm{mL})\end{array}$ & $\begin{array}{c}\text { Measured total } \\
\text { fraction volume } \\
(\mathrm{mL})\end{array}$ & $\begin{array}{c}\text { Calculated } \\
\text { volume } \\
(\mathrm{mL})\end{array}$ & $\begin{array}{c}\text { Downstream } \\
\text { pressure } \\
\text { (bar) }\end{array}$ \\
\hline FT072495MLC & $2.0 \mathrm{~mL} / \mathrm{h}$ & 25.15 & 25.41 & 25.17 & 1.0 \\
FT072695MLC & $2.0 \mathrm{~mL} / \mathrm{h}$ & 27.50 & 27.72 & 27.67 & none \\
FT080695MLC & $0.2 \mathrm{~mL} / \mathrm{h}$ & 28.40 & 27.47 & 28.30 & none \\
FT081495MLC & $2.0 \mathrm{~mL} / \mathrm{h}$ & 27.53 & 26.87 & 27.67 & none \\
FT081695MLC & $0.2 \mathrm{~mL} / \mathrm{h}$ & 28.97 & 25.39 & 29.00 & none \\
\hline
\end{tabular}

The variation in instantaneous permeability with confining pressure (Figure 2) can be explained by a change in the fracture aperture that depends on confining pressure. In the example shown the effective aperture width need only change by $\sim 0.06 \mu \mathrm{m}$ to cause the change in permeability observed. The significant effects of both confining pressure and pore pressure on permeability in fractured materials make it clear that flow and transport experiments that have been conducted using samples that are embedded in an impermeable medium (e.g., epoxy) will not exhibit these effects.

Reproducibility of tracer breakthrough curves - Figures 5-8 show examples of $\mathrm{I}^{-}$tracer breakthrough curves for replicated run conditions. The results indicate that, with the exception of the data in figure 8, replication is quite good. These results suggest complete flushing of the tracer between flow test runs and no significant changes to the hydrologic or chemical state of the sample. They also indicate that pore-pressure, confining pressure, and flow rate effects are essentially reversible.

Effect of flow rate, pore pressure, and temperature on breakthrough of tracer - Figures 9 and 10 show that the tracer elutes sooner (volumetrically) and exhibits less tailing at the lower flow rate. This effect appears to be independent of pore pressure. Apparently, tracer that has diffused into the matrix of the sample is more effectively "swept" out at the slow flow rate than at the faster rate; i.e., the diffusion rate of tracer from the matrix to the fracture following the passage of the pulse maximum relative to the flow rate through the fracture is such that the tailing region of the breakthrough curve is minimized.

Figures 11-12 show the effect of pore pressure on the breakthrough of the tracer. These figures show that the initial breakthrough is retarded and the tailing region of the pulse is extended relative to the case where pore pressure is low. This suggests that pore pressure controls the fracture/matrix connectivity and/or controls the width of micro-fractures that may emanate from the main fracture pathway.

Figures 13-15 show the role that temperature plays in controlling the initial breakthrough and the extent of tailing in the tracer pulse. The volumetric elution of the tracer occurs earlier, and the tailing is less pronounced the greater the temperature of the experiment. This effect is most likely related to the increase in diffusion coefficient for the tracer and shows that retardation expected to result from the diffusion of radionuclides into the matrix is reduced with increasing temperature.

Chemistry of effluent fluids - Table 3 shows chemical analyses for selected elements in the effluent fluids prior to, during, and after the breakthrough of the tracer. The major observation is the positive correlation of dissolved $\mathrm{Si}$ with temperature and the negative correlation of $\mathrm{Si}, \mathrm{Ca}$, and $\mathrm{Mg}$ with flow rate (at $92^{\circ} \mathrm{C}$ ). 
The latter correlation is most evident in a comparison of the concentrations of the samples taken during and after the tracer pulse. The pre-tracer sample collected at the $2.0 \mathrm{~mL} / \mathrm{h}$ flow rate at $92{ }^{\circ} \mathrm{C}$ is apparently significantly affected by the effluent composition of the previous $0.2 \mathrm{~mL} / \mathrm{h}$ experiment. The silica concentrations observed in the $0.2 \mathrm{~mL} / \mathrm{h}$ runs are consistent with silica levels expected for equilibrium with quartz. Preliminary calculations based on the geometric surface area of the fracture and the average residence time of fluid in the fracture suggest that the observed fluid concentrations of $\mathrm{Si}$ are consístent with laboratory derived rates of quartz dissolution.

Table 3. Concentrations $(\mathrm{mg} / \mathrm{L})$ of selected elements for selected flow tests.

\begin{tabular}{|c|c|c|c|c|c|c|c|c|c|c|}
\hline \multirow[t]{2}{*}{ Element } & \multirow{2}{*}{$\begin{array}{l}\text { Feed } \\
\text { solution }\end{array}$} & \multicolumn{3}{|c|}{ FT0 $41495,23^{\circ} \mathrm{C}, 0.2 \mathrm{~mL} / \mathrm{h}$} & \multicolumn{3}{|c|}{$\mathrm{FT} 080695,92^{\circ} \mathrm{C}, 0.2 \mathrm{~mL} / \mathrm{h}$} & \multicolumn{3}{|c|}{ FT081495, $92^{\circ} \mathrm{C}, 2.0 \mathrm{~mL} / \mathrm{h}$} \\
\hline & & Pre-tr ${ }^{1}$ & Tracer & Post-tr & Pre-tr & Tracer & Post-tr & Pre-tr & Tracer & Post-tr \\
\hline $\mathrm{Ca}$ & 0.05 & 2.05 & 4.67 & 4.54 & 3.30 & 4.13 & 3.62 & 3.71 & 2.95 & 2.46 \\
\hline $\mathrm{Mg}$ & $<0.01$ & 0.46 & 1.09 & 1.08 & 0.74 & 0.85 & 0.83 & 0.83 & 0.60 & 0.53 \\
\hline $\mathrm{Na}$ & 33 & 36 & 43 & 37 & 35 & 38 & 34 & 34 & 32 & 31 \\
\hline K & $<0.01$ & 0.2 & 0.4 & 0.4 & 1.5 & 2.2 & 1.7 & 1.6 & 1.6 & 1.2 \\
\hline $\mathrm{Si}$ & 0.08 & 0.49 & 2.75 & 2.65 & 18.74 & 20.92 & 22.49 & 23.24 & 8.54 & 6.91 \\
\hline $\mathrm{Sr}$ & $<0.02$ & 0.07 & 0.13 & 0.12 & 0.07 & 0.03 & 0.09 & 0.08 & 0.3 & 0.06 \\
\hline
\end{tabular}

${ }^{1}$ Pre-tr - sample collected before the tracer was injected; Tracer - sample collected during the elution of the tracer; Post-tr - sample collected after the complete elution of the tracer.

\section{Conclusions}

The effects of confining pressure, pore pressure, flow rate, and temperature on permeability and transport of a conservative tracer through a saw-cut sample of Topopah Spring tuff have been measured. These effects can be significant and are likely to affect the degree of retardation of radionuclides in fractured materials in the near field environment of the potential repository at Yucca Mountain. Increasing pore pressure tends to increase the retardation due to matrix diffusion; increasing temperature has the opposite effect.

These findings strengthen the argument that transport experiments for fractured samples must be undertaken using flow-test apparatuses that allow the variation of confining and pore pressures, because not only is the permeability of the sample affected, but also the nature of the breakthrough curve. Experiments that have previously been conducted with core samples that were epoxied in place do not provide data to test phenomena which would be expected to play a role in the transport of radionuclides through fractured media at Yucca Mountain. Hence, relationships between physical variables such as pore pressure and confining pressure and chemical phenomena such as radionuclide transport will not be adequately accounted for in transport and performance assessment models unless transport experiments are undertaken using the type of apparatus used in this study.

\section{References}

De Marsily, G. 1986. Quantitative Hydrogeology. p. 55 Academic Press, Inc. New York.

Viani, B.E. and Martin, S.I. 1993. Core-Flow Through Apparatus: Letter Report Documenting Testing Phase. YMP Milestone Report M0L06.

Viani B.E. and Martin, S.I. 1994. Core Flow Experiment Protocol. YMP Milestone Report M0L04. 


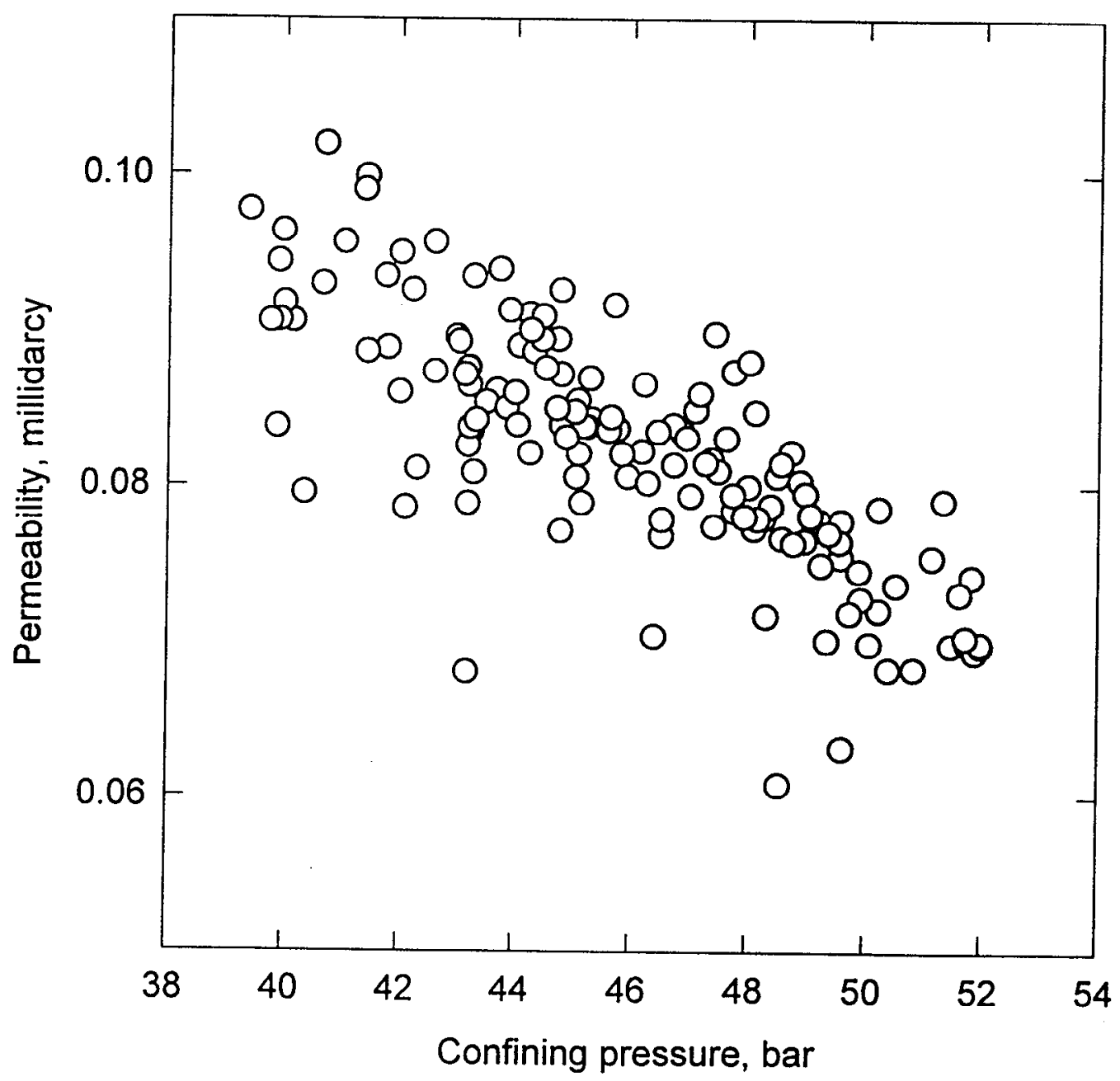

Figure 2. Variation in permeability due to variation in confining pressure for flow test FT050295 $(\mathrm{T}=$ $59^{\circ} \mathrm{C}$; flow rate $=0.2 \mathrm{~mL} / \mathrm{h}$ ). 


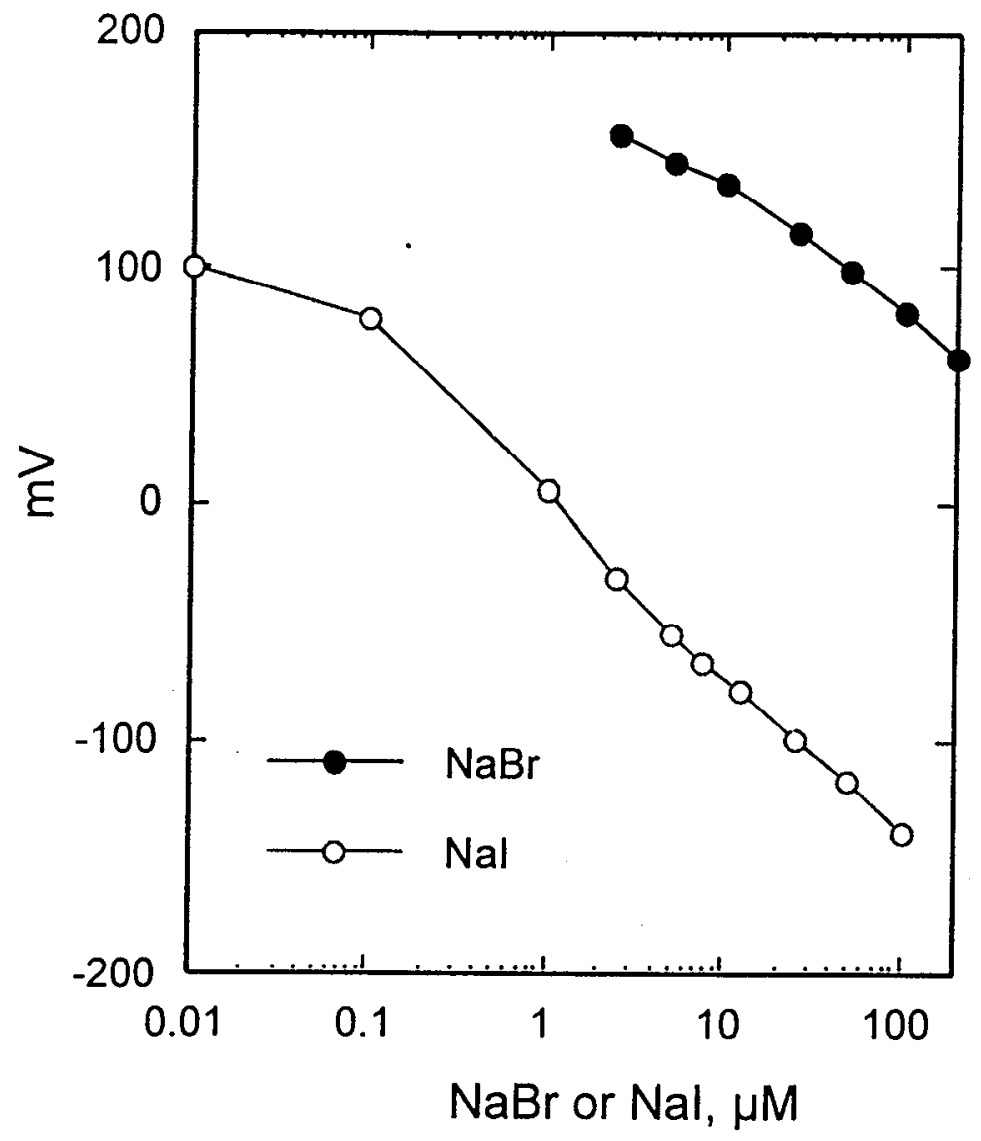

Figure 3. Standard curves for $\mathrm{Br}^{-}$and $\mathrm{I}^{-}$measurement using ion selective electrode. 


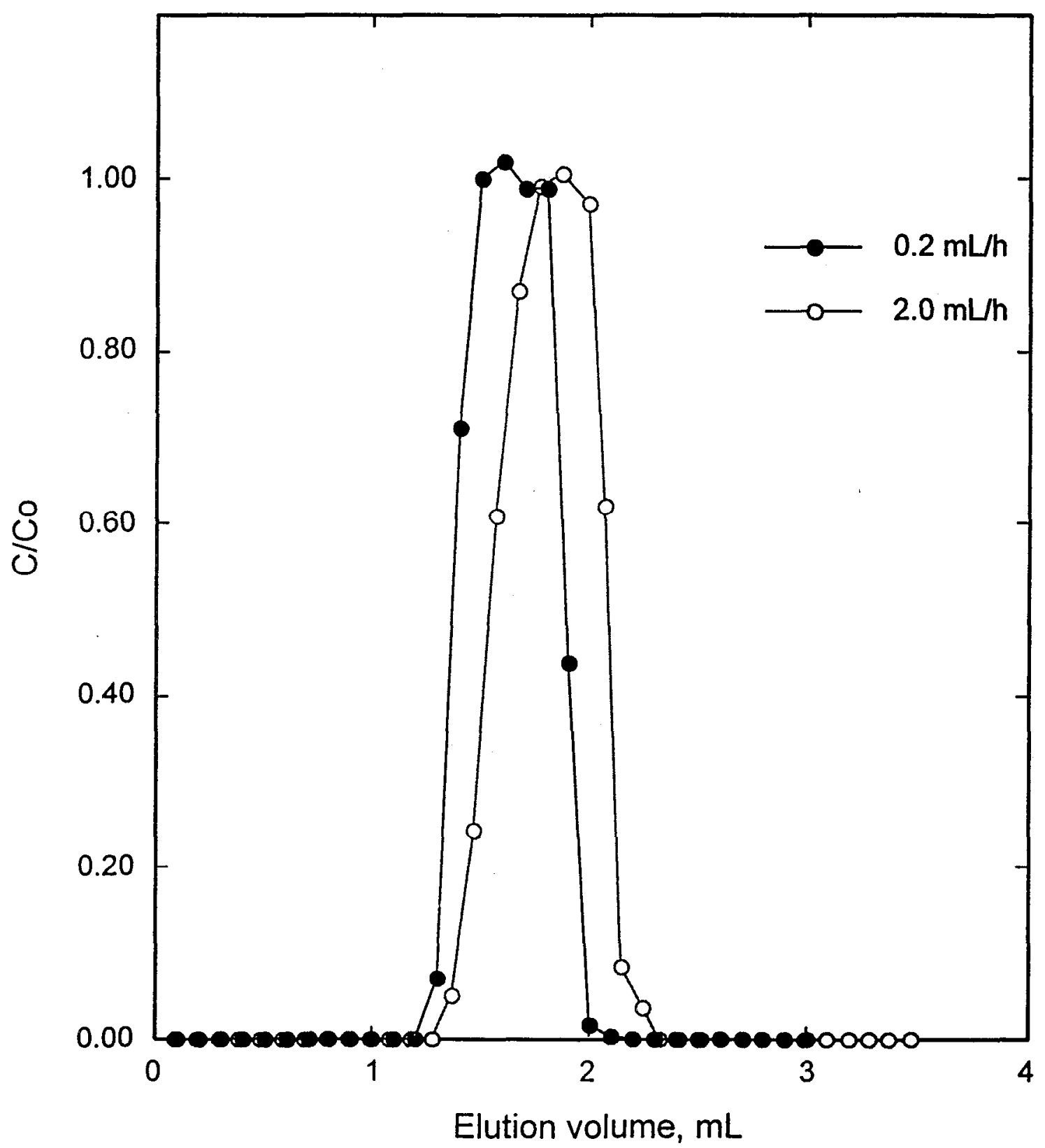

Figure 4. Dispersion of $500 \mu \mathrm{L}$ of I tracer after passing $70 \mathrm{~cm}$ of $1 / 16^{\prime \prime} \mathrm{ID}$ tubing at 0.2 and $2.0 \mathrm{~mL} / \mathrm{h}$. $\mathrm{C} / \mathrm{C}_{0}$ is the relative concentration of the tracer pulse $\left(\mathrm{C}_{0}=0.75 \mathrm{mM}\right)$. 


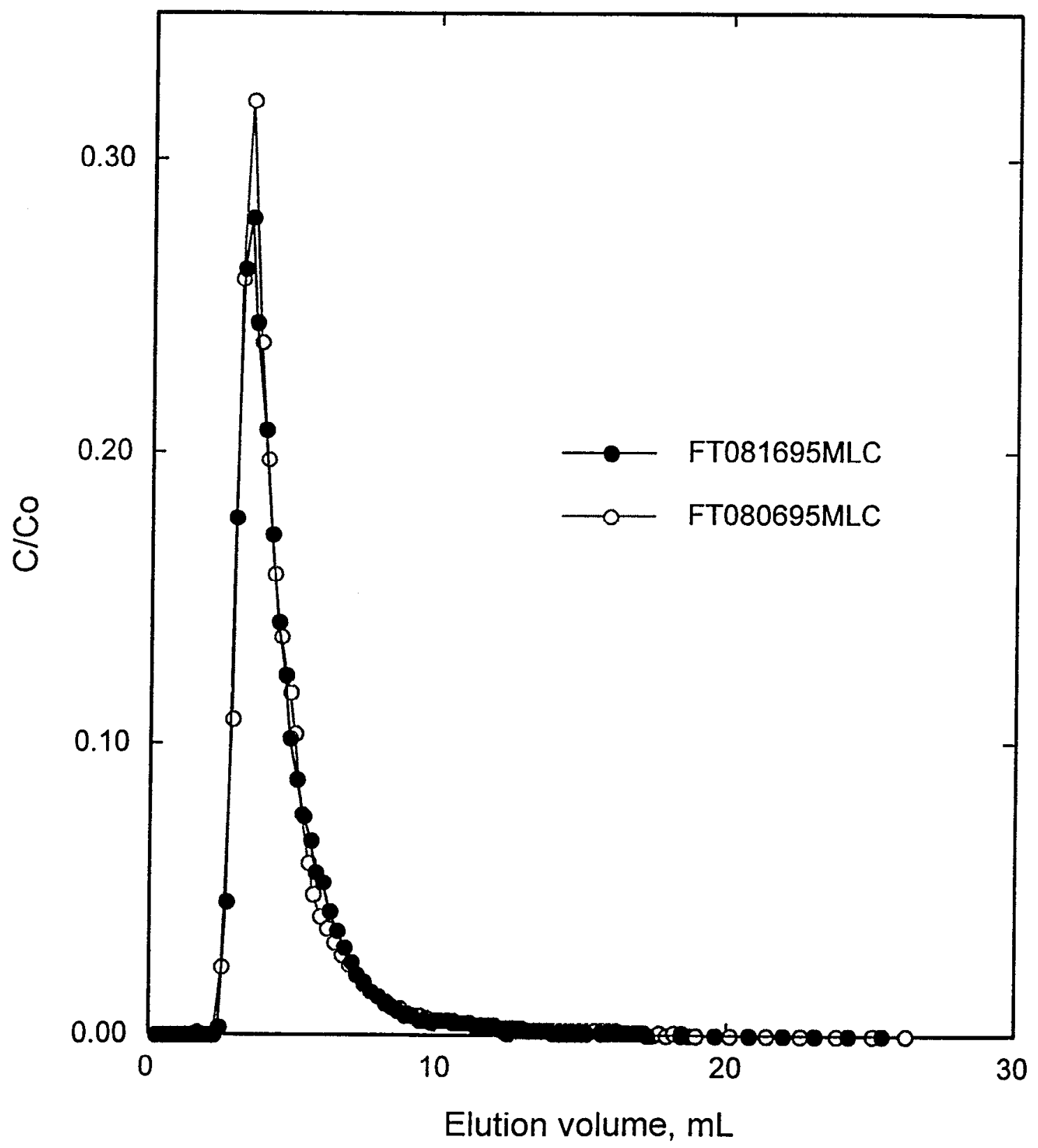

Figure 5. Relative concentration $\left(\mathrm{C} / \mathrm{C}_{0}\right)$ breakthrough of $560 \mu \mathrm{L}$ pulses of $\mathrm{I}^{-}$tracer for $0.2 \mathrm{~mL} / \mathrm{h}$ flow rate, $92{ }^{\circ} \mathrm{C}$, and low pore pressure. 


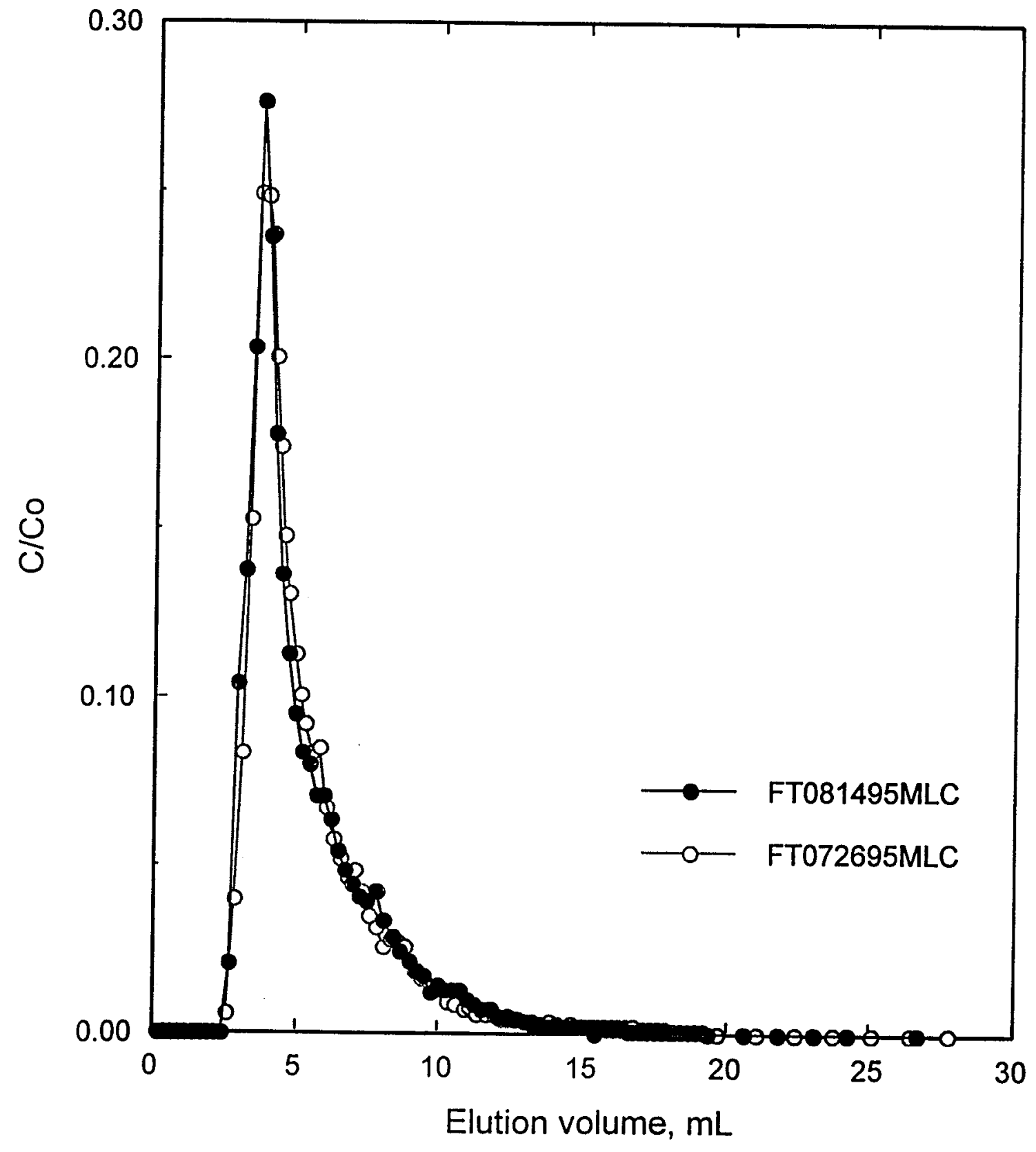

Figure 6. Relative concentration $\left(\mathrm{C} / \mathrm{C}_{\mathrm{o}}\right)$ breakthrough of $560 \mu \mathrm{L}$ pulses of $\mathrm{I}^{-}$tracer for $2.0 \mathrm{~mL} / \mathrm{h}$ flow rate, $92{ }^{\circ} \mathrm{C}$, and low pore pressurc. 


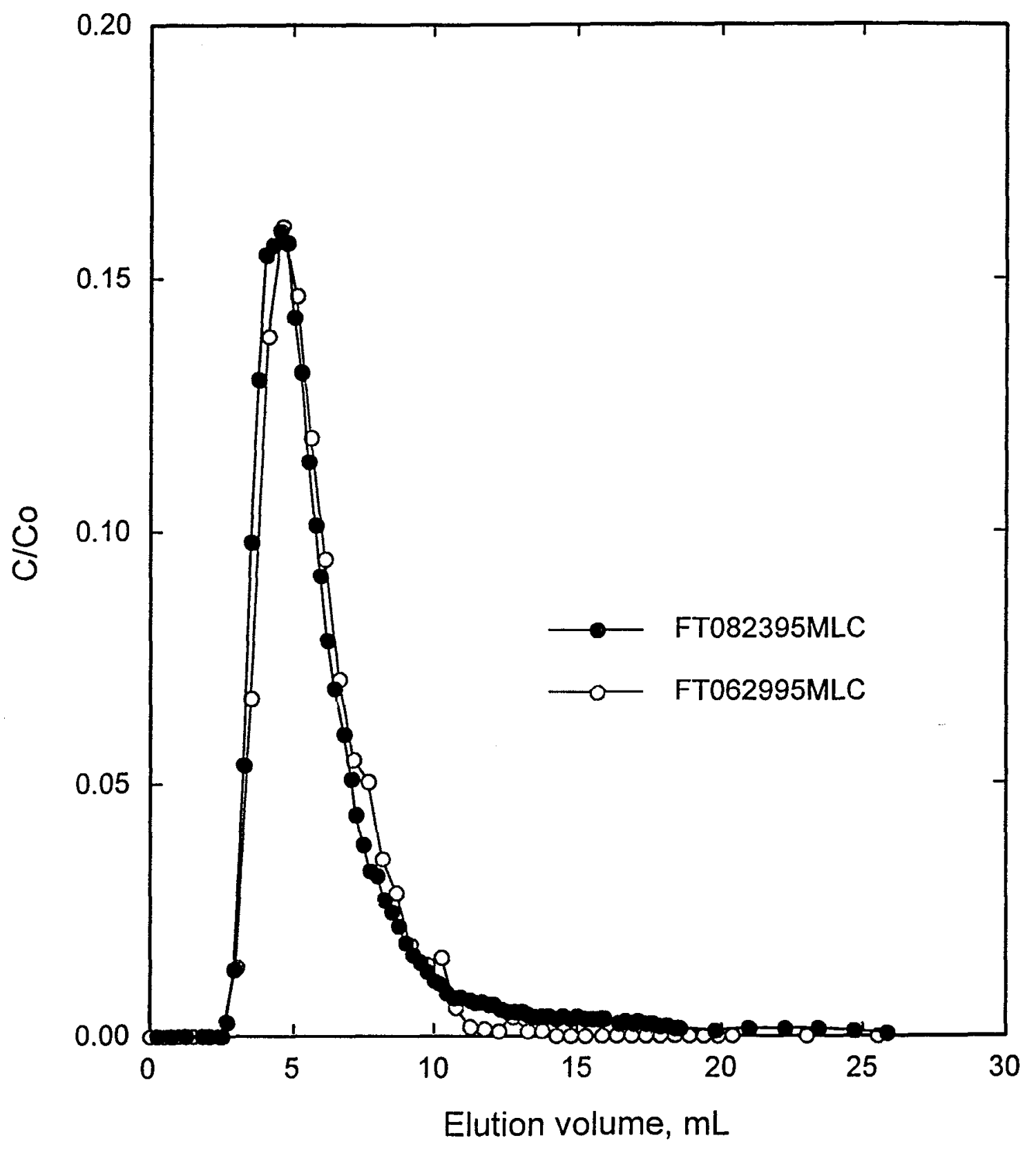

Figure 7. Relative concentration $\left(C / C_{0}\right)$ breakthrough of $560 \mu \mathrm{L}$ pulses of $I^{-}$tracer for $0.2 \mathrm{~mL} / \mathrm{h}$ flow rate, $92^{\circ} \mathrm{C}$, and 1 bar pore pressure. 


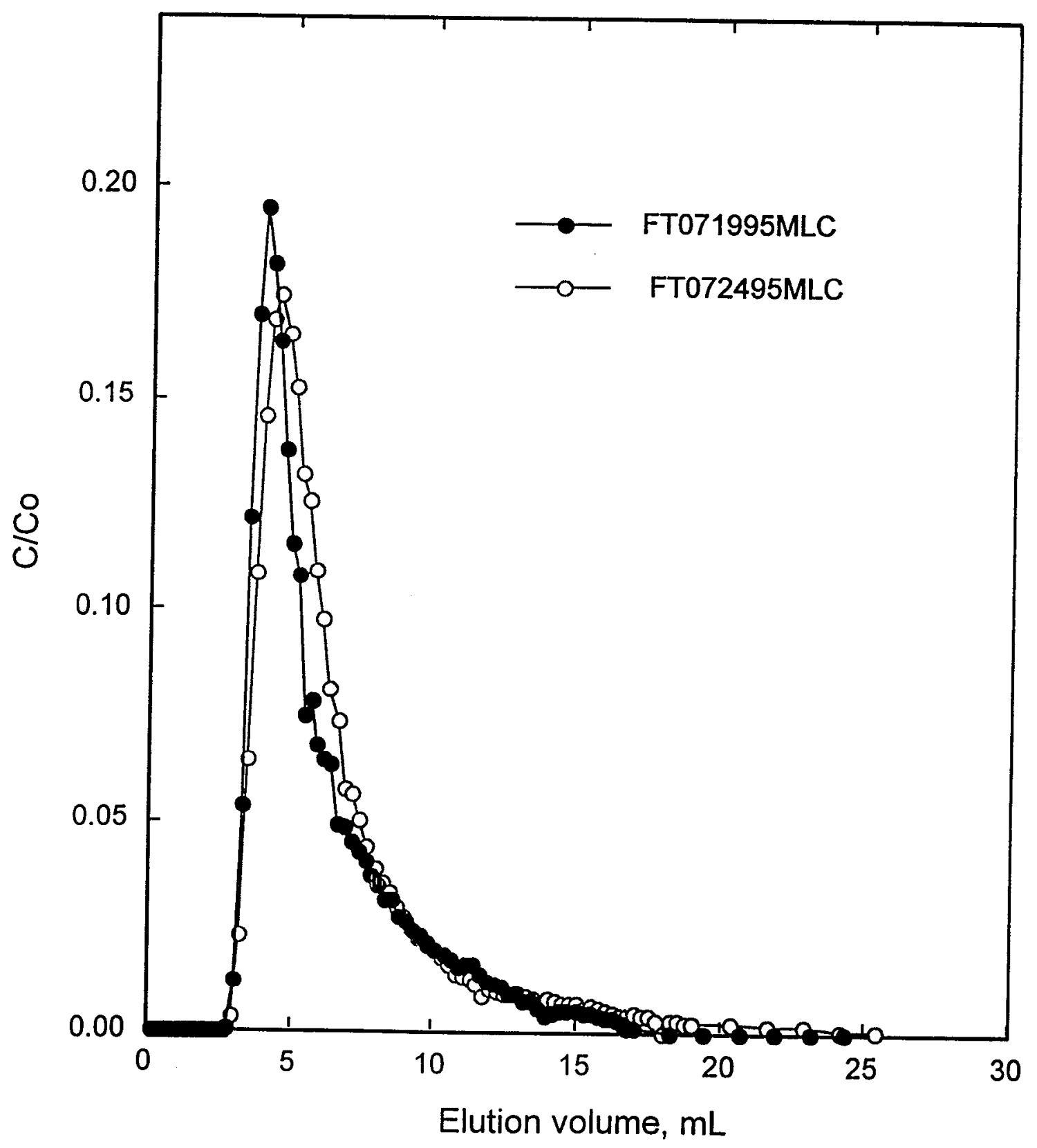

Figure 8. Relative concentration $\left(\mathrm{C} / \mathrm{C}_{\mathrm{o}}\right)$ breakthrough of $560 \mu \mathrm{L}$ pulses of $\mathrm{I}$ tracer for $2.0 \mathrm{~mL} / \mathrm{h}$ flow rate, $92{ }^{\circ} \mathrm{C}$, and 1 bar pore pressure. 


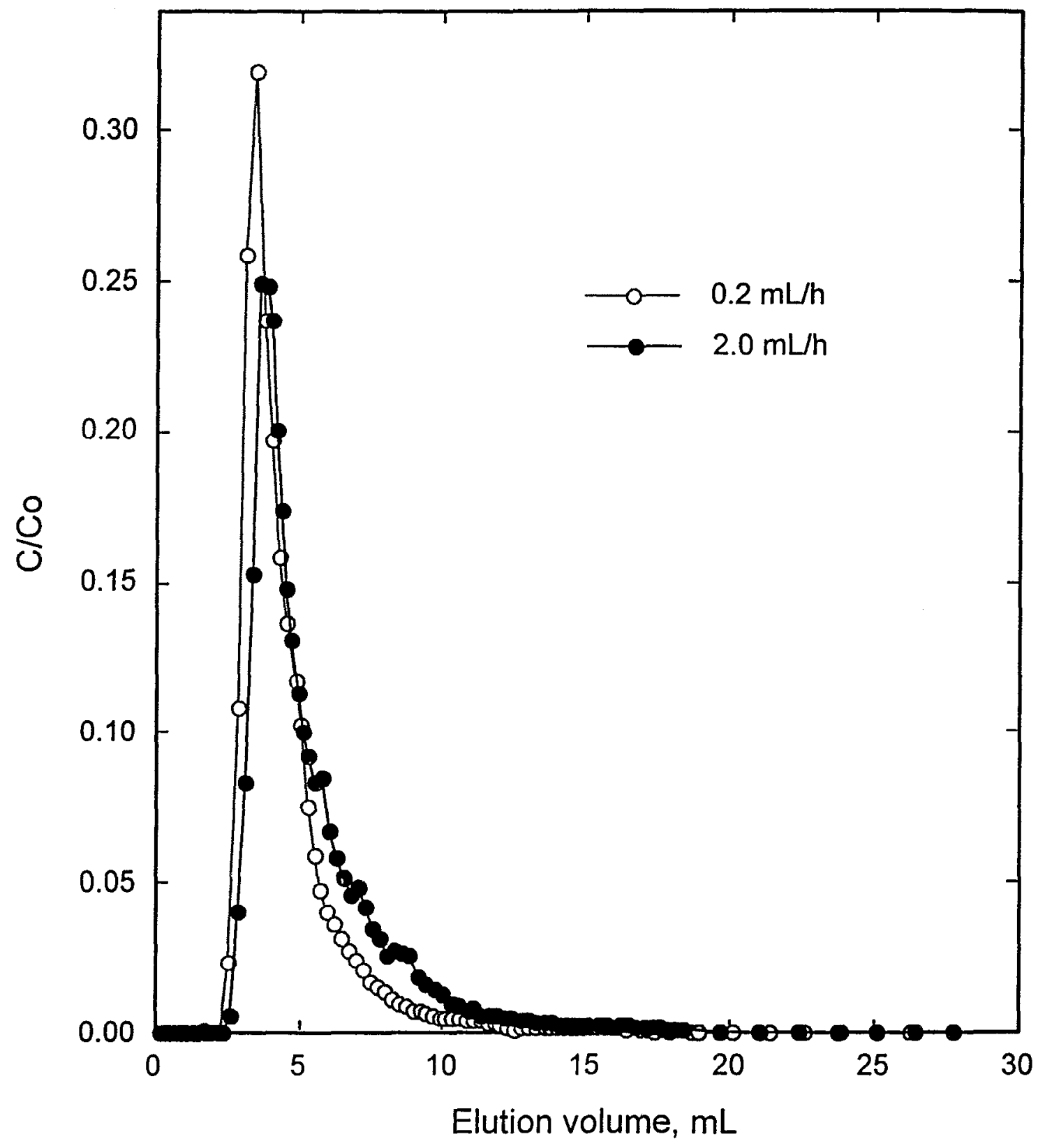

Figure 9. Relative concentration $\left(\mathrm{C} / \mathrm{C}_{\mathrm{o}}\right)$ breakthrough of $560 \mu \mathrm{L}$ pulse of $\mathrm{I}^{-}$tracer for 0.2 (FT080695MLC) and 2.0 (FT072695MLC) $\mathrm{mL} / \mathrm{h}$ flow rates at $92{ }^{\circ} \mathrm{C}$ and low pore pressure. 


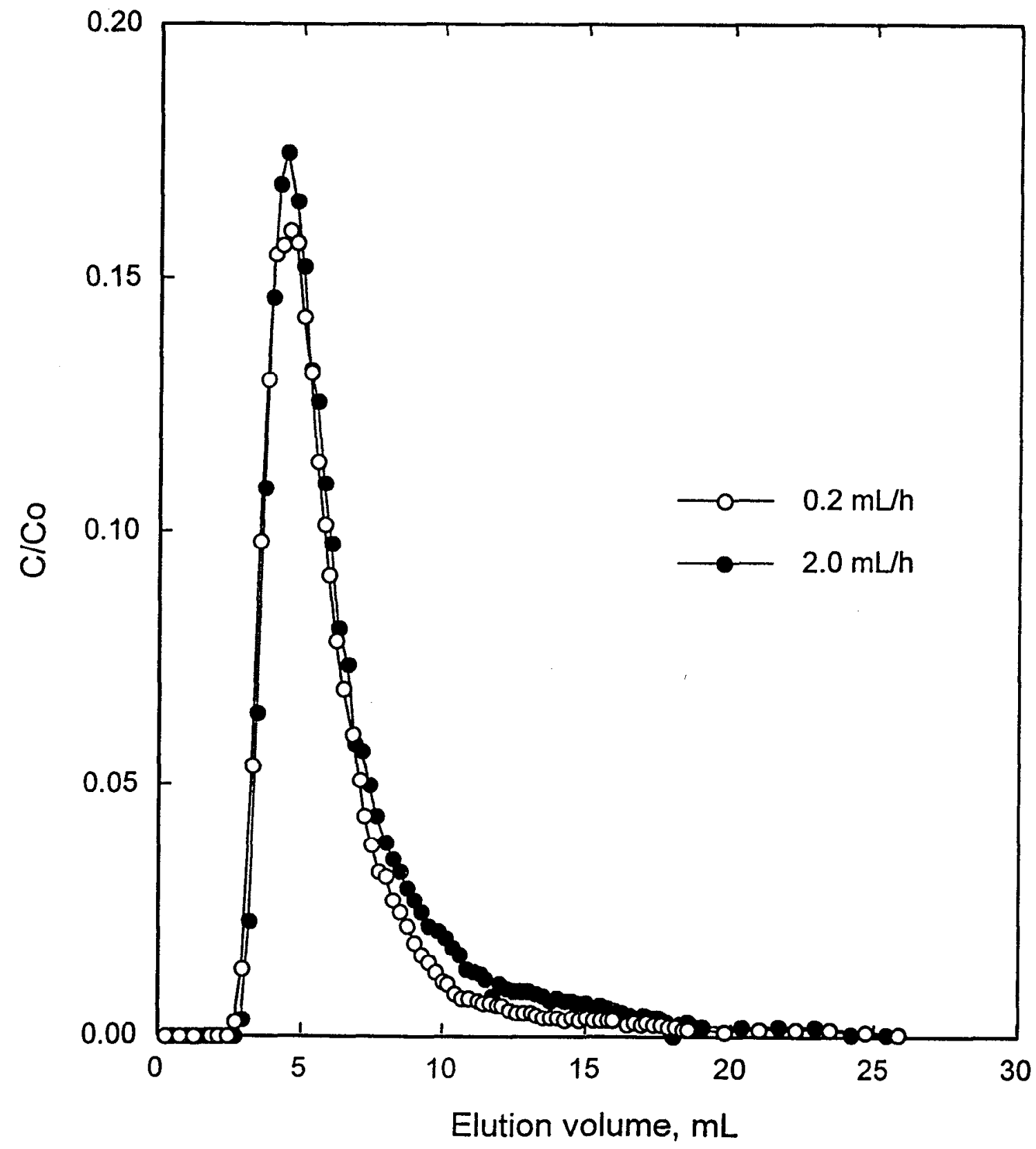

Figure 10. Relative concentration $\left(\mathrm{C} / \mathrm{C}_{\mathrm{o}}\right)$ breakthrough of $560 \mu \mathrm{L}$ pulse of $\mathrm{I}^{-}$tracer for 0.2 (FT082395MLC) and 2.0 (FT072495MLC) $\mathrm{mL} / \mathrm{h}$ flow rates at $92{ }^{\circ} \mathrm{C}$ and 1 bar pore pressure. 


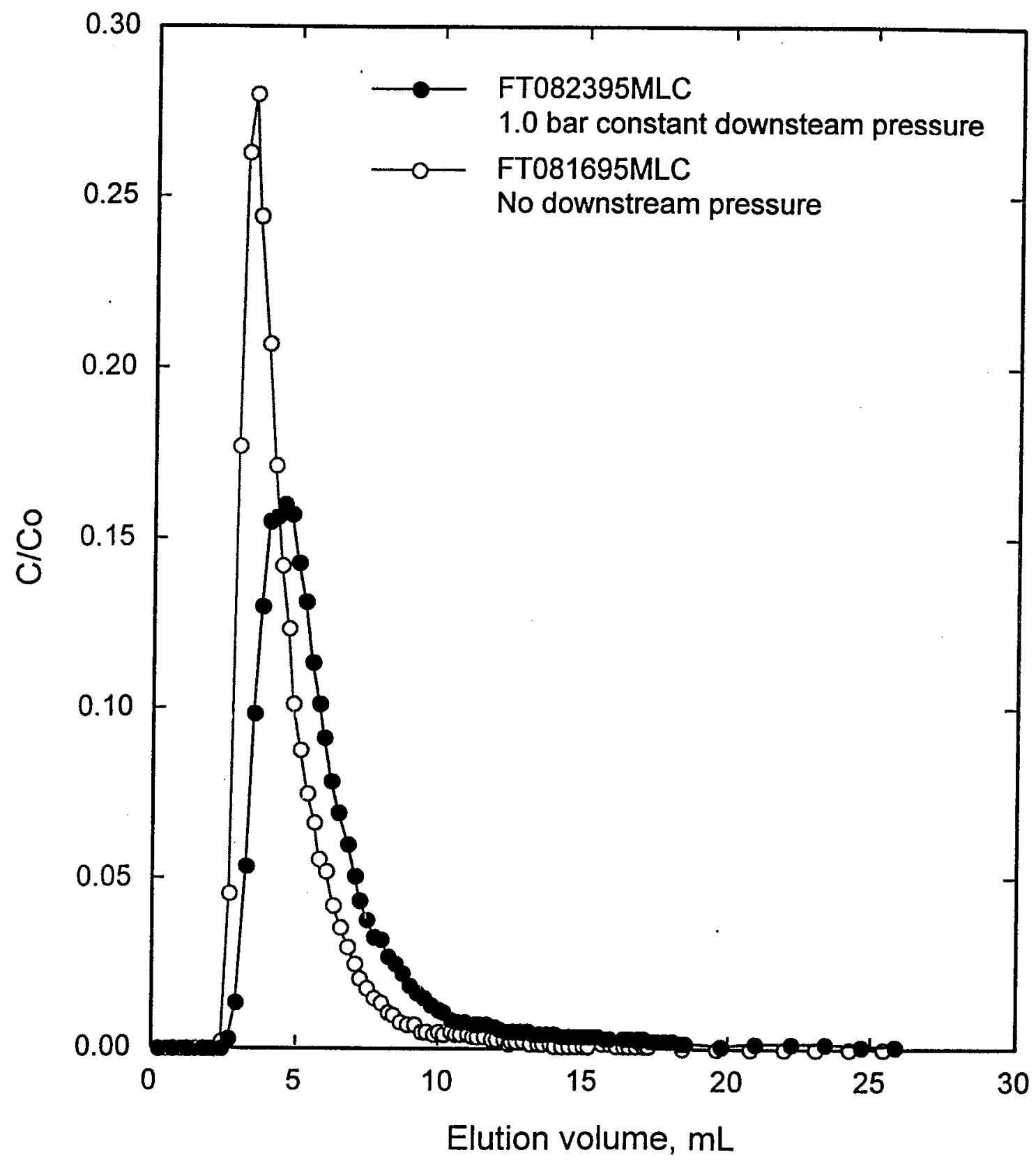

Figure 11. Relative concentration $\left(\mathrm{C} / \mathrm{C}_{0}\right)$ breakthrough of $560 \mu \mathrm{L}$ pulse of $\mathrm{I}$ tracer for $0.2 \mathrm{~mL} / \mathrm{h}$ flow rate at $92{ }^{\circ} \mathrm{C}$ and 1 bar (FT082395MLC) and low (FT081695MLC) pore pressure. 


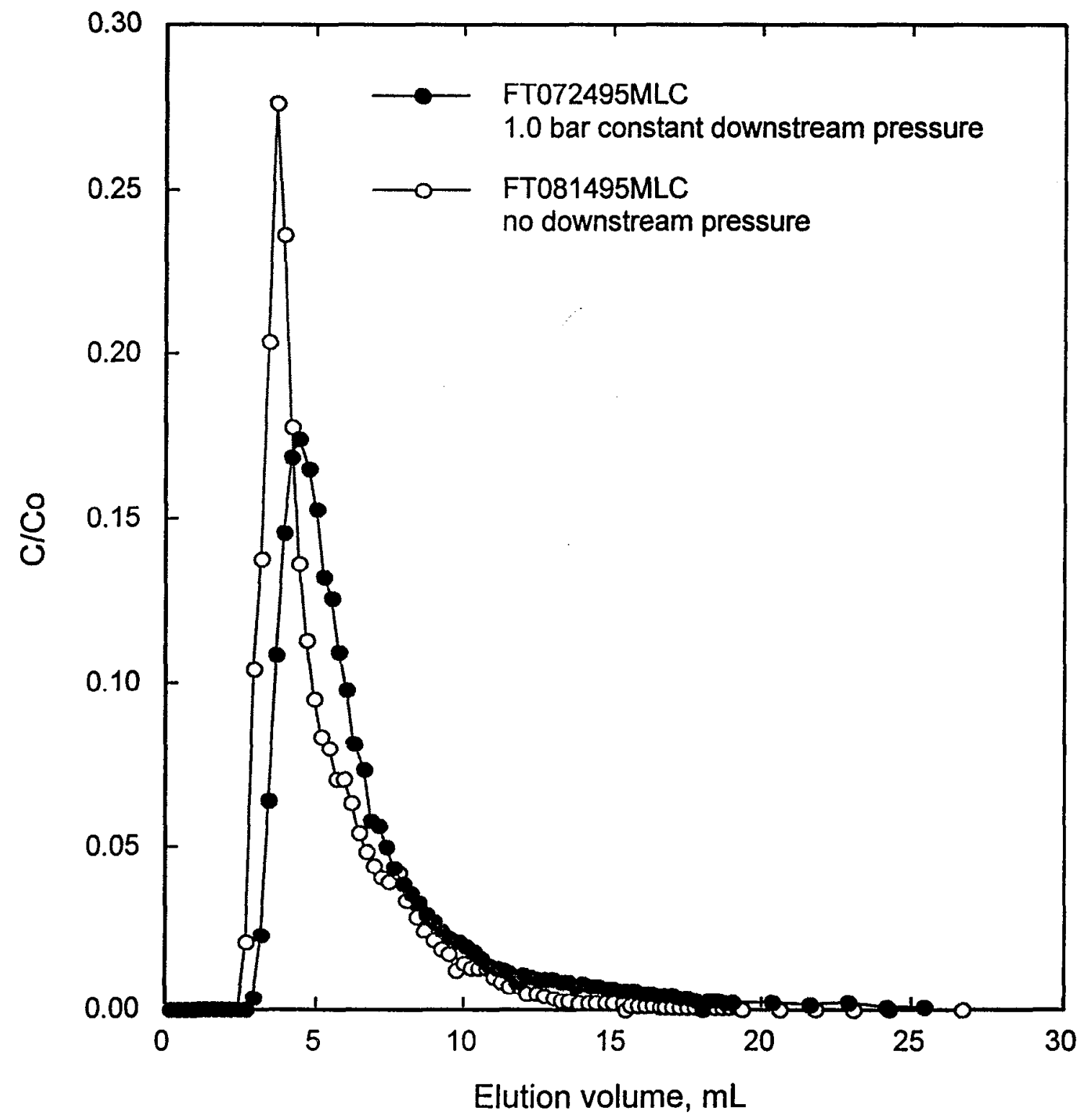

Figure 12. Relative concentration $\left(C / C_{0}\right)$ breakthrough of $560 \mu \mathrm{L}$ pulse of $\mathrm{I}^{-}$tracer for $2.0 \mathrm{~mL} / \mathrm{h}$ flow rate at $92{ }^{\circ} \mathrm{C}$ and 1 bar (FT072495MLC) and low (FT081495MLC) pore pressure. 


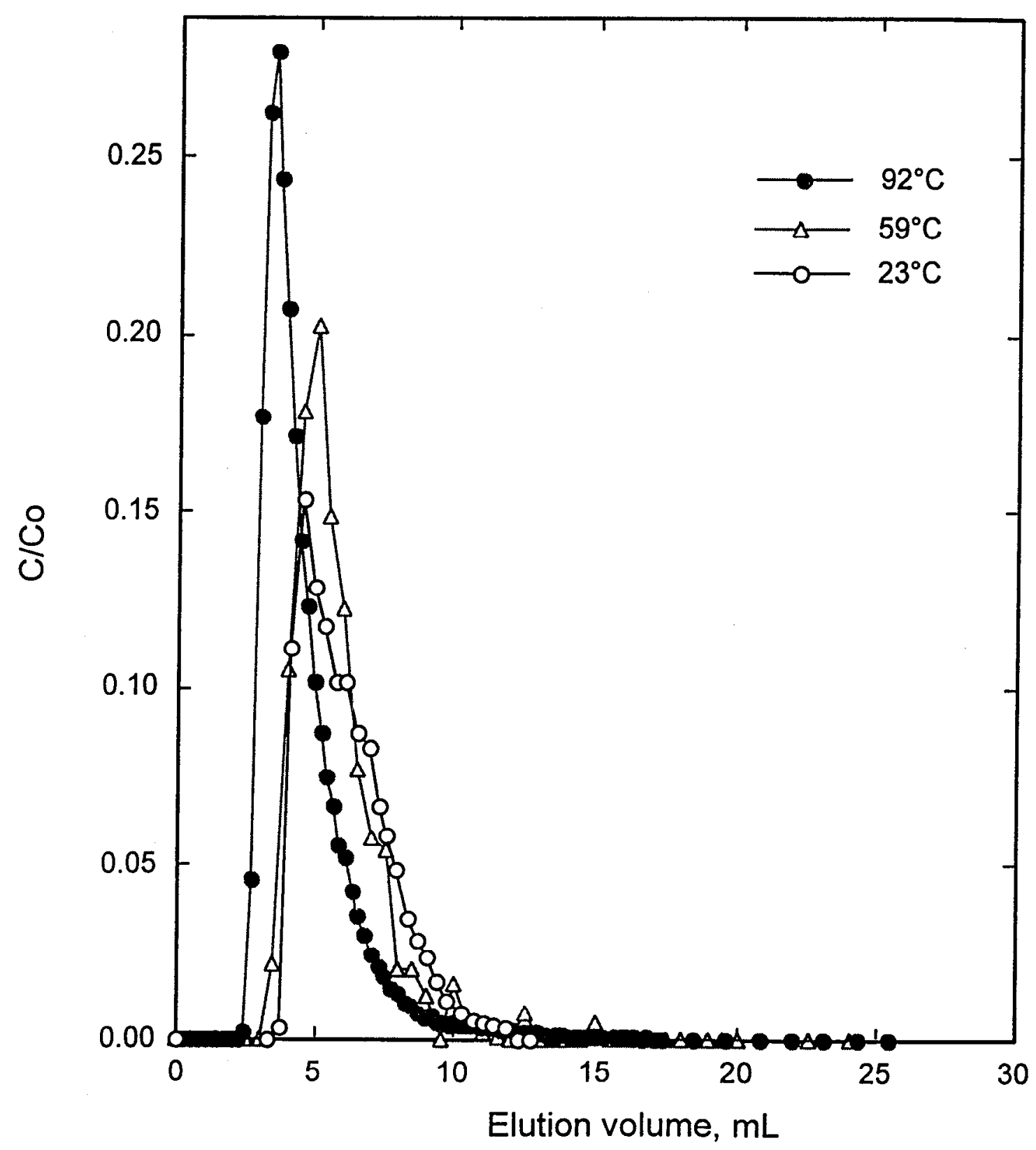

Figure 13. Relative concentration $\left(\mathrm{C} / \mathrm{C}_{0}\right)$ breakthrough of $560 \mu \mathrm{L}$ pulse of $\mathrm{I}^{-}$tracer for 0.1 and $0.2 \mathrm{~mL} / \mathrm{h}$ flow rates at 23 (FT040495MLC), 59 (FT051295MLC) and 92 (FT081695MLC) ${ }^{\circ} \mathrm{C}$ and low pore pressure. 


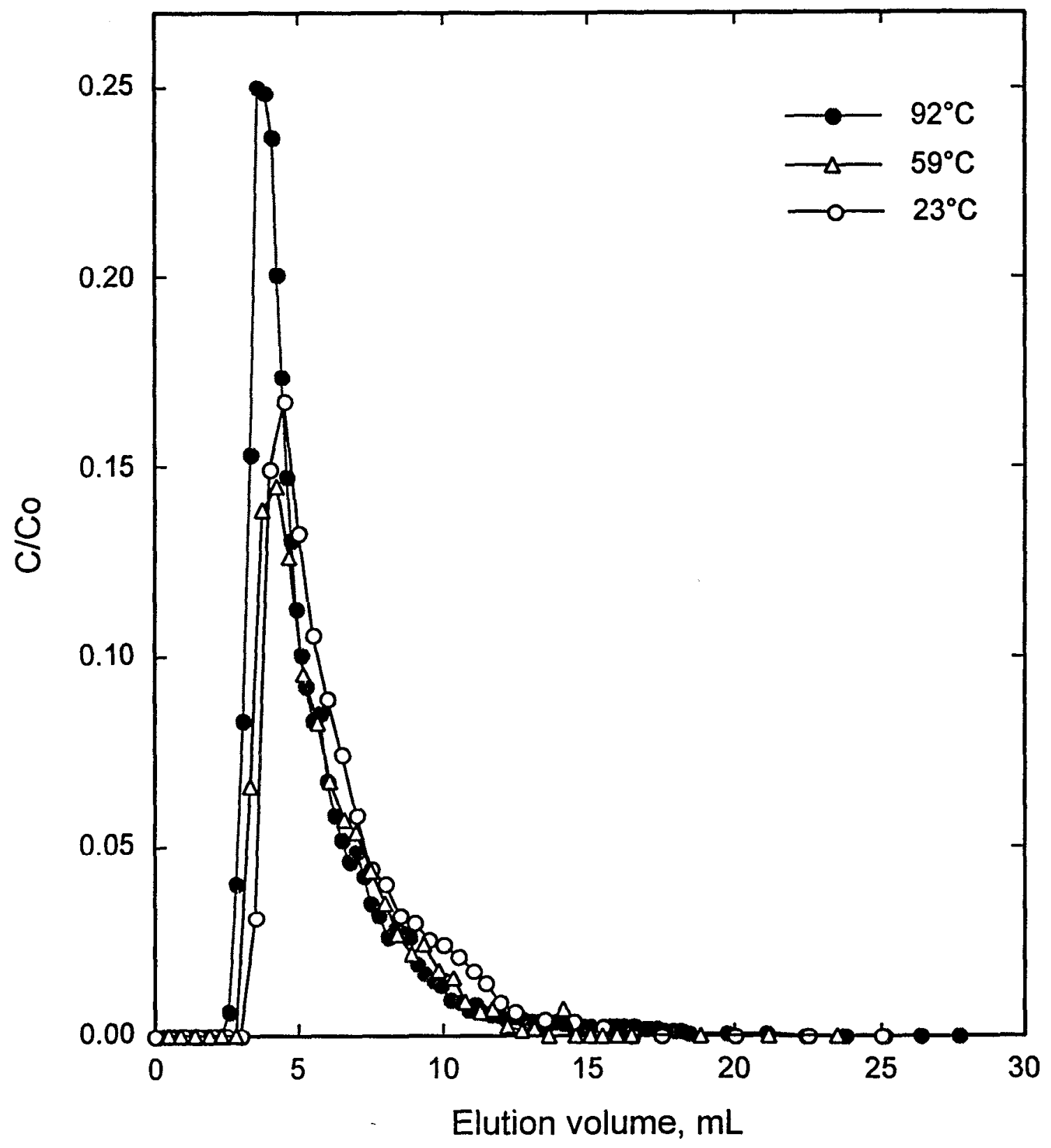

Figure 14. Relative concentration $\left(\mathrm{C} / \mathrm{C}_{\mathrm{o}}\right)$ breakthrough of $560 \mu \mathrm{L}$ pulse of $\mathrm{I}^{-}$tracer for $2.0 \mathrm{~mL} / \mathrm{h}$ flow rate at 23(FT040395MLC), 59 (FT051095MLC) and 92 (FT072695MLC) ${ }^{\circ} \mathrm{C}$ and low pore pressure. 


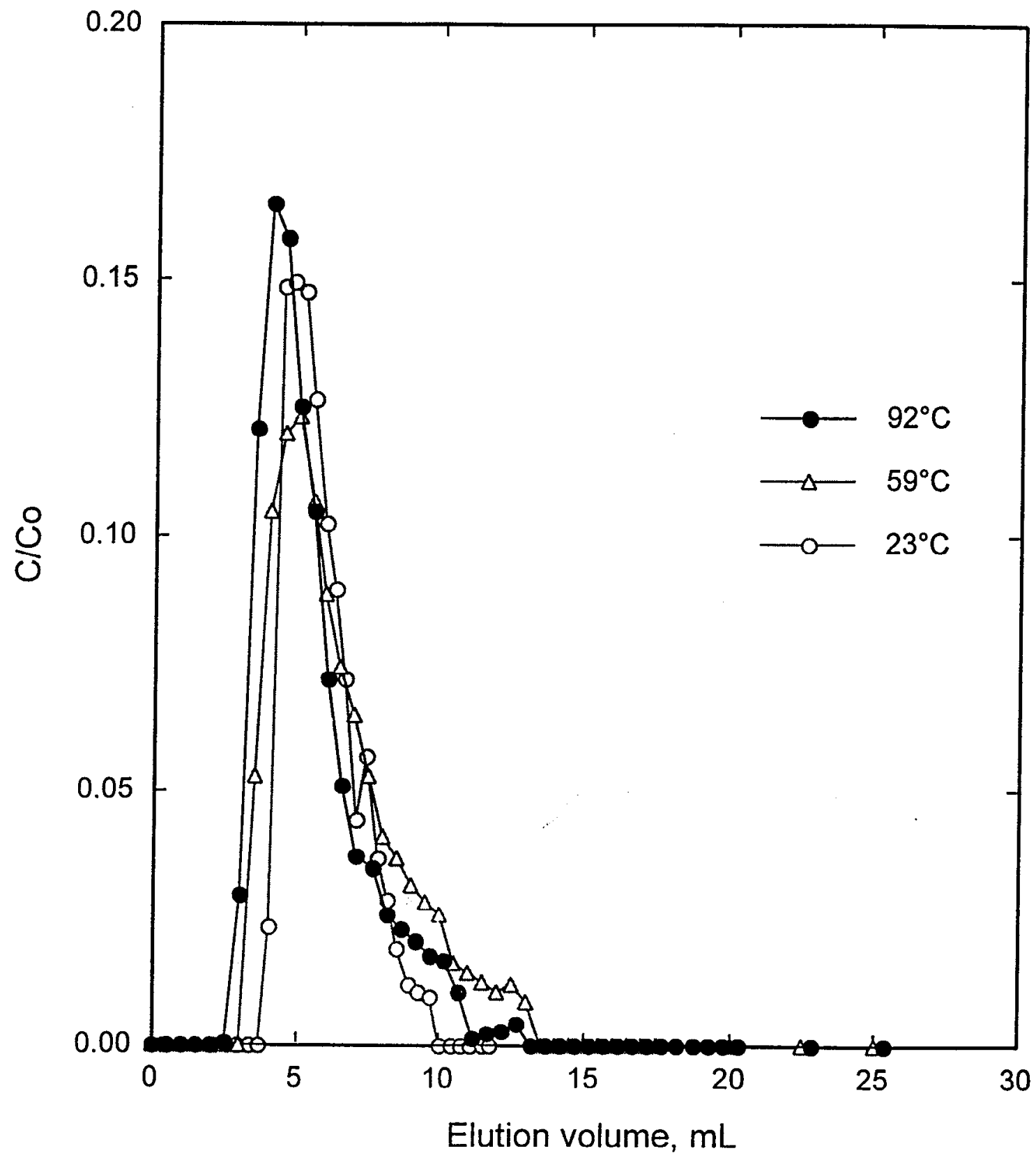

Figure 15. Relative concentration $\left(\mathrm{C} / \mathrm{C}_{0}\right)$ breakthrough of $560 \mu \mathrm{L}$ pulse of $\mathrm{I}^{-}$tracer for $0.2 \mathrm{~mL} / \mathrm{h}$ flow rate at 23(FT041495MLC), 59 (FT050295MLC) and 92 (FT061595MLC) ${ }^{\circ} \mathrm{C}$ at pore pressures of $0.47,2.5$, and 2.88 bar, respectively. 


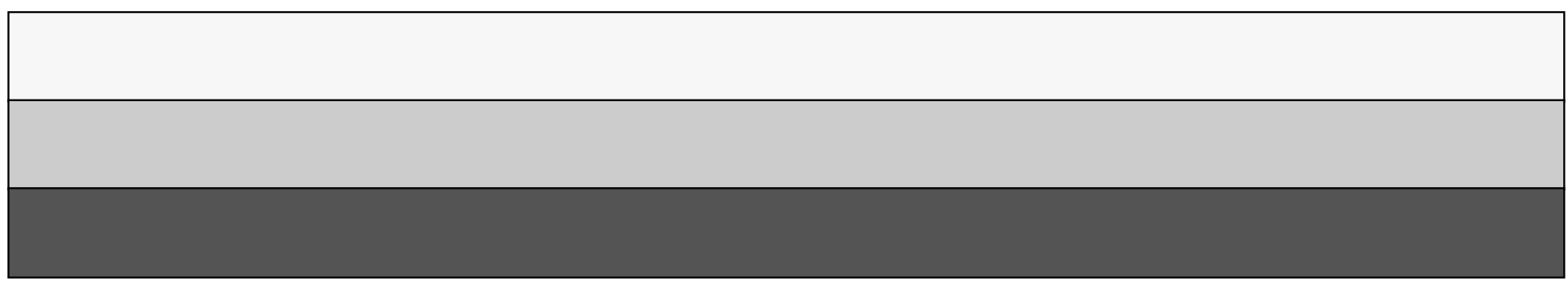

